Postgate, J. R. (1956). J. gen. Microbiol. 15, 186-193

\title{
Iron and the Synthesis of Cytochrome $c_{3}$
}

\author{
By J. R. POSTGATE \\ The Chemical Research Laboratory, Teddington, Middlesex
}

\begin{abstract}
SUMMARY: Desulphovibrio desulphuricans (El Agheila Z), in lactate + sulphate media, required $10 \mathrm{~m} \mu$ mole $\mathrm{Fe} / \mathrm{ml}$. for optimal growth; no absolute iron requirement was demonstrable in pyruvate + sulphate media but iron up to $20 \mathrm{~m} \mu \mathrm{mole} / \mathrm{ml}$. stimulated growth. In a sulphate-deficient pyruvate medium, in which this strain can grow, iron was not required nor did it stimulate growth. Organisms grown with limited iron formed limited amounts of cytochrome $c_{3}$, and in the absence of iron were markedly deficient in this ; their content of hydrogenase was reduced to a lesser extent and their content of desulphoviridin was only halved. Iron-deficient organisms were able to reduce sulphate only slowly. Less than $1 \%$ of the iron added to cultures was accounted for as cytochrome $c_{3}$, though only some $6 \%$ of this iron remained in solution after growth.
\end{abstract}

The demonstration of cytochrome $c_{3}$ as a component of the anaerobic sulphatereducing bacteria (see Postgate, 1956, for references) provided at least a partial explanation of their requirement for traces of iron (Butlin, Adams \& Thomas, 1949). The present paper reports a study of the effect of iron on the synthesis of cytochrome $c_{3}$, desulphoviridin (the porphyroprotein-like pigment which absorbs at $630 \mathrm{~m} \mu$.), and of hydrogenase by a strain of these bacteria chosen because of its ability to grow without sulphate when pyruvate is present (Postgate, 1952).

\section{METHODS}

Organism. Desulphovibrio desulphuricans strain El Agheila Z (National Collection of Industrial Bacteria, NCIB, no. 8380) was a variant, containing hydrogenase, of the organism isolated from a sulphur-producing lake in Libya (Adams, Butlin, Hollands \& Postgate, 1951). It was subcultured weekly under $\mathrm{H}_{2} 95 \%(\mathrm{v} / \mathrm{v}) \mathrm{CO}_{2} 5 \%(\mathrm{v} / \mathrm{v})$ at $30^{\circ}$ in LSY medium (see below); its purity was checked as described by Postgate (1953).

Media. Medium LSY consisted mainly of lactate, sulphate and yeast extract; it was similar to medium $C$ of Butlin et al. (1949) but was supplemented with $2 \cdot 5 \% \mathrm{NaCl}$. Medium PY was a sulphate-deficient medium containing pyruvate and yeast extract (Postgate, 1952). Medium PSY was a similar medium supplemented with $\mathrm{Na}_{2} \mathrm{SO}_{4}(18 \mu \mathrm{mole} / \mathrm{ml}$.).

Inocula. For routine subculture $0.05 \mathrm{ml}$. of parent culture was added to $5 \mathrm{ml}$. fresh medium. For growth tests in media of defined iron concentration a smaller inoculum was used to avoid carry-over; the parent culture was diluted c. $1 / 2500$ to give $0 \cdot 1 \mu \mathrm{g}$. dry wt. organisms $/ \mathrm{ml}$. subculture $\left(c .4 \times 10^{5}\right.$ viable bacteria/ml.), the concentrations of medium components being adjusted so that the final volume after all additions was $5 \mathrm{ml}$.; $\mathrm{Na}_{2} \mathrm{~S}(5 \mu \mathrm{mole} / \mathrm{ml}$.) was included in all media to adjust the redox potential to $c$. $-200 \mathrm{mv}$. and thus to ensure growth of this relatively small inoculum (see Grossman \& Postgate, 1953). 
Iron-free reagents and glassware. Media and solutions to be added were prepared with analytical grade reagents and freed from iron with 8-hydroxyquinoline (Waring \& Werkman, 1942), except that $\mathrm{Na}_{2} \mathrm{~S}$ solutions were assumed to be effectively iron-free owing to the low solubility product of FeS. Chromic acid-washed Pyrex glassware was freed from adsorbed iron as recommended by Waring \& Werkman; all-glass Seitz filters, used for sterilizing $\mathrm{Na}_{2} \mathrm{~S}$ solutions and media PY and PSY, were freed from adsorbed iron by washing successively with chromic acid, distilled water, a solution of 8-hydroxyquinoline in water saturated with chloroform, chloroform, and iron-free distilled water.

Culture in media of defined iron concentration. Cotton-wool plugs are unsuitable for use with iron-deficient media because of their high iron content. On the other hand, aluminium or glass-capped test-tubes are not entirely suitable for use with cultures of exacting anaerobes in an anaerobic jar, since the gas phase in the jar cannot be changed without the risk of sweeping contaminant micro-organisms under the caps as the new gas phase enters the evacuated jar. This procedure was nevertheless adopted, cultures in test-tubes with aluminium caps being stood in McIntosh \& Fildes anaerobic jars on filter-paper wetted with dilute $\mathrm{CuSO}_{4}$ solution; cultures were frequently examined microscopically for contaminants, and doubtful ones tested as described by Postgate (1953). In fact, only one culture out of 300 or 400 used in this work contained a contaminant. Duplicate cultures were set up at all iron concentrations, and crucial tests were repeated three times.

Larger quantities of bacteria were grown in 'iron-free' Pyrex glass flasks with beakers as caps, or, when $c .2$ l. of culture was required, in 'iron-free' flasks with cotton-wool plugs protected with washed gauze. The use of $\mathrm{Na}_{2} \mathrm{~S}$ as a supplement to the test media ensured growth of the relatively small inocula necessary to eliminate carry-over of iron, but it had the disadvantage that iron could not conveniently be tested at concentrations above $20 \mathrm{~m} \mu \mathrm{mole} / \mathrm{ml}$. because at this concentration turbidity due to $\mathrm{FeS}$ appeared on addition of $\mathrm{Na}_{2} \mathrm{~S}$. This observation supports Seidell (1940), who quoted a value of 70.1 $\mathrm{m} \mu$ mole $/ \mathrm{ml}$. for the saturation solubility of $\mathrm{FeS}$ at $18^{\circ}$ but stated that this figure was probably too high.

Spectrophotometry. The application of Barer's (1955) procedure to the spectrophotometry of intact Desulphovibrio desulphuricans is described elsewhere (Postgate, 1956). The cytochrome $c_{3}$ content of the bacteria was measured at $554 \mathrm{~m} \mu$., since, though the Soret peak at $419 \mathrm{~m} \mu$. would have been a far more sensitive index of $c_{3}$ content, the green protein desulphoviridin absorbs at $411 \mathrm{~m} \mu$. and would be expected to interfere at low concentrations of $c_{3}$. Organisms suspended in strong serum albumin solution were reduced with $\mathrm{Na}_{2} \mathrm{~S}_{2} \mathrm{O}_{4}$ in $0.5 \mathrm{~cm}$. optical cells and the absorption relative to reduced controls was determined at $554 \mathrm{~m} \mu$.; the specific extinction coefficient of cytochrome $c_{3}$ was taken as 4.2 and the absorption due to $c_{3}$ calculated from a hypothetical linear scatter curve using the arithmetical extrapolation below $(d=$ cell density in mg. dry wt./ml.):

$$
\text { mg. } c_{3} / \text { g. air-dry wt. }=\frac{2}{4 \cdot 2 \times 10^{-3} d}\left[\epsilon_{554}-\left(\epsilon_{570}+\frac{\epsilon_{538}-\epsilon_{570}}{2}\right)\right] .
$$


Several spectra of intact bacteria in the $500-600 \mathrm{~m} \mu$. range showed that this expression could legitimately be used provided the absolute optical density of the test suspension was below $2 \cdot 0$.

Cytochrome $c_{3}$ contents of bacteria are also quoted as $\mu$-units $(\mu \mathrm{U}) /$.$g .;$ $1 \mu \mathrm{U}$. would equal $1 \mu$ mole if the millimolar extinction coefficient were 54 , the value to be expected for a bifunctional haematohaematin.

Desulphoviridin contents of bacteria were estimated by plotting the spectrum of intact organisms between 600 and $660 \mathrm{~m} \mu$. and estimating the height of the inflexion at $630 \mathrm{~m} \mu$.; they are expressed in arbitrary units : optical density at $630 \mathrm{~m} \mu$./g. dry wt. bacteria.

Hydrogenase activity. The hydrogenase content of the organisms was judged by the rate of reduction of methylene blue: $2 \cdot 6-3 \mathrm{mg}$. dry wt. organisms in buffer $\left(\mathrm{KH}_{2} \mathrm{PO}_{4} \mathbf{0 . 5} \%, \mathrm{w} / \mathrm{v}, \mathrm{pH} 6 \cdot 30 \pm 0 \cdot 02,+\mathrm{NaCl} 2 \cdot 5 \%, \mathrm{w} / \mathrm{v}\right)$ were incubated in conventional Warburg manometers under $\mathrm{H}_{2}$ at $37^{\circ}$ for at least $1 \mathrm{hr}$. before tipping in $7.5 \mu$ mole substrate; this pre-incubation was necessary to obtain maximum reduction rates.

Sulphide estimation. Cultures for sulphide determination were grown in vacuo in sealed 'iron-free' Pyrex tubes. Immediately after opening them, sulphide was determined iodometrically as described by Grossman \& Postgate (1955), applying their correction: iodine equivalent to $2 \cdot 2 \mu$ mole $S^{\prime \prime} / \mathrm{ml}$. absorbed by $1 \mathrm{mg}$. dry wt. bacteria/ml.

Bacterial densities. These were measured turbidimetrically in the E.E.L. colorimeter (Evans Electroselenium Ltd.) calibrated with the Hildenborough strain of these bacteria.

\section{RESULTS}

Iron requirement of Desulphovibrio desulphuricans, Strain El Agheila Z. This strain required $10 \mathrm{~m} \mu$ mole $\mathrm{Fe} / \mathrm{ml}$. for optimal growth in medium LSY (Fig. 1). Little iron remained after growth with a suboptimal iron concentration. The supernatant fluid from a 5-day culture in medium LSY $+7.5 \mathrm{~m} \mu$ mole $\mathrm{Fe} / \mathrm{ml}$. was acidified, concentrated tenfold and analysed for iron with $o$-phenanthroline (Sandell, 1944); it contained only $0.48 \mathrm{~m} \mu \mathrm{mole} \mathrm{Fe} / \mathrm{ml}$., equivalent to $6 \cdot 4 \%$ of the amount added initially.

Strain El Agheila $\mathrm{Z}$ had no demonstrable requirement for iron in medium PSY, but iron up to $20 \mathrm{~m} \mu \mathrm{mole} / \mathrm{ml}$. stimulated growth; growth was not linearly related to iron concentration. In medium PY the organism had again no requirement for added iron, and iron up to $20 \mathrm{~m} \mu \mathrm{mole} / \mathrm{ml}$. had little or no effect on growth (Fig. 1).

Sulphate reduction by iron-deficient cells. The bacterial densities reached in iron-deficient media PSY and PY were similar, and suggested that, even in the presence of sulphate, only 'sulphate-deficient' growth occurred. The rate of sulphide formation in medium PSY with and without iron was therefore determined. The results are recorded in Table 1 : with $20 \mathrm{~m} \mu$ mole $\mathrm{Fe} / \mathrm{ml}$. all the available sulphate was reduced in less than $100 \mathrm{hr}$.; without Fe only about half was reduced after $550 \mathrm{hr}$. Though a lower bacterial density was reached in the absence of $\mathrm{Fe}$, this was nevertheless half that reached in its presence and could 
not account for the tenfold lowering in rate of sulphide formation. Mucopolysaccharide formation, mentioned by Grossman \& Postgate (1955), occurred in both media and rendered determinations of optical density invalid after prolonged incubation. It was formed at an earlier stage in medium PSY than in medium PY; detailed quantitative data were not obtained.

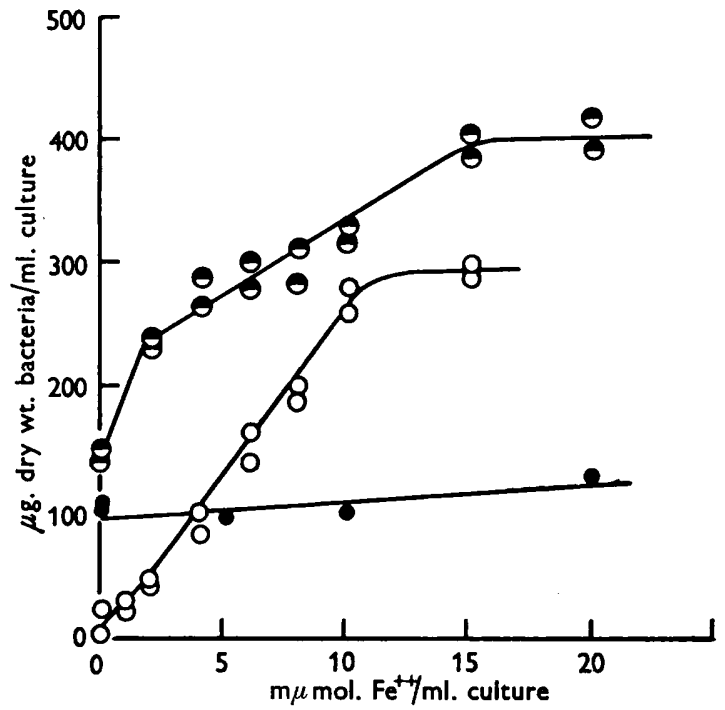

Fig. 1. Effect of iron on growth of Desulphovibrio desulphuricans in lactate or pyruvate media. Cultures of $D$. desulphuricans strain $\mathrm{El}$ Agheila $\mathrm{Z}$ were incubated in lactate or pyruvate media of known iron content $\left(\mathrm{FeSO}_{4} \cdot\left(\mathrm{NH}_{4}\right)_{2} \mathrm{SO}_{4}\right.$ for media PSY and LSY; $\mathrm{FeCl}_{2}$ for medium PY), and the amounts of growth determined after 5 days of incubation. $O=$ medium LSY; $\boldsymbol{\theta}=$ medium PSY; $\boldsymbol{O}=$ medium PY.

Table 1. Sulphide formation by Desulphovibrio desulphuricans (El Agheila Z) in pyruvate medium with and without added iron

Iron-deficient medium PSY (see text) was distributed in iron-free tubes, inoculated (c. $3 \mu \mathrm{g}$. dry wt. organisms $/ \mathrm{ml}$.), sealed in vacuo and incubated at $30^{\circ}$. Pairs of tubes were opened and the amounts of growth and sulphide concentrations were determined at intervals.

Incubation
time
(hr.)
72
120
144
216
230
360
550

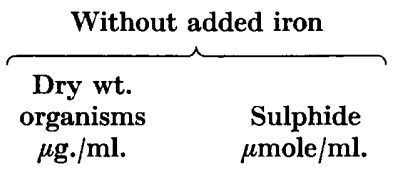

48

90

150

140

$130 *$

$105^{*}$

c. 50*

$-\overline{2 \cdot 33}$
$2 \cdot 18$
$2 \cdot 70$
$4 \cdot 62$
$3 \cdot 90$
$4 \cdot 50$

With $20 \mathrm{~m} \mu \mathrm{mol}$. $\mathrm{Fe}\left(\mathrm{NH}_{4}\right)_{2}\left(\mathrm{SO}_{4}\right)_{2} / \mathrm{ml}$.

$\begin{array}{cc}\begin{array}{c}\text { Dry wt. } \\ \text { organisms } \\ \mu \mathrm{g} . / \mathrm{ml} .\end{array} & \begin{array}{c}\text { Sulphide } \\ \mu \mathrm{mole} / \mathrm{ml} .\end{array} \\ 260 & 5 \cdot 43 \\ 295 & \mathbf{8 \cdot 1} \\ 240 & \mathbf{8 \cdot 8 5} \\ 300^{*} & 9 \cdot 2 \\ 290^{*} & \mathbf{8 \cdot 8 5} \\ 185^{*} & 9 \cdot 75 \\ \text { c. 30* } & 9 \cdot 25\end{array}$

* The optical densities of these suspensions were diminished by mucopolysaccharide formation; hence these readings are low. 
Iron deficiency decreased the activity of suspensions of bacteria to an even greater extent. Organisms grown in an iron-deficient medium reduced sulphate in the presence of hydrogen at only about one-fiftieth of the rate observed with organisms grown with iron (Table 3). The decline may in fact have been greater than this, since the quoted $Q$ values imply a net difference between blank and control vessels of 3 to $6 \mathrm{~mm}^{3} \mathrm{H}_{2}$ absorbed over $1 \frac{1}{2} \mathrm{hr}$., a difference which is close to the limit of sensitivity of the manometric procedure used. The decline in rate of sulphate reduction could not be due to deficiency in hydrogenase, since there was only a fivefold to eightfold decrease in the hydrogenase activity of iron-deficient organisms (below).

Effect of iron on content of cytochrome $c_{3}$. Waring \& Werkman (1944) showed that iron-deficient Aerobacter indologenes was deficient in cytochrome. The fact that the iron requirement of strain $\mathrm{El}$ Agheila $\mathrm{Z}$ depended on the test medium permitted a quantitative study of this effect in Desulphovibrio desulphuricans. Bacteria grown in medium LSY containing $5,7.5$ or $10 \mathrm{~m} \mu$ mole $\mathrm{Fe} / \mathrm{ml}$. contained cytochrome $c_{3}$ in concentrations proportional to the iron concentration (Table 2). Organisms harvested from pyruvate media (PY and PSY) contained plentiful cytochrome $c_{3}$ when iron was present in the medium; in the absence of iron cytochrome $c_{3}$ was present only in very small amounts and was undetectable unless very heavy suspensions were used in the spectrophotometer. Provided iron were present, however, cytochrome $c_{3}$ was found both in the presence and absence of sulphate.

Table 2. Cytochrome $\mathrm{c}_{3}$ and desulphoviridin contents of Desulphovibrio desulphuricans grown in media of defined iron concentration

Batches (250 ml. to 1 l.) of $D$. desulphuricans strain $\mathrm{El}$ Agheila $\mathrm{Z}$ were grown in irondeficient media with known amounts of added iron (as $\mathrm{FeCl}_{2}$ or $\left.\mathrm{Fe}\left(\mathrm{NH}_{4}\right)_{2}\left(\mathrm{SO}_{4}\right)_{2}\right)$, centrifuged, and the content of cytochrome $c_{3}$ and desulphoviridin/g. dry wt. organisms was determined spectrophotometrically (see text).

\begin{tabular}{|c|c|c|c|c|}
\hline \multirow[b]{2}{*}{ Medium } & \multirow{2}{*}{$\begin{array}{l}\text { Added iron } \\
(\mathrm{m} \mu \mathrm{mole} / \mathrm{ml} .)\end{array}$} & \multicolumn{2}{|c|}{ cytochrome $c_{3}$ content } & \multirow{2}{*}{$\begin{array}{l}\text { content } \\
\text { (optical density } \\
\text { value/g.) }\end{array}$} \\
\hline & & (mg./g.) & ( $\mu \mathrm{U} \cdot /$ g.) & \\
\hline $\begin{array}{l}\text { LSY } \\
\text { LSY } \\
\text { LSY }\end{array}$ & $\begin{array}{r}5 \\
7 \cdot 5 \\
10\end{array}$ & $\begin{array}{l}1 \cdot 19 \\
1 \cdot 35 \\
1 \cdot 87\end{array}$ & $\begin{array}{l}0 \cdot 091 \\
0 \cdot 104 \\
0 \cdot 144\end{array}$ & $\begin{array}{l}6 \cdot 4 \\
5 \cdot 1 \\
6 \cdot 1\end{array}$ \\
\hline $\begin{array}{l}\text { PY } \\
\text { PY }\end{array}$ & $\overline{20}$ & $\begin{array}{l}0 \cdot 121 \\
2 \cdot 3\end{array}$ & $\begin{array}{l}0 \cdot 0093 \\
0 \cdot 177\end{array}$ & $\begin{array}{l}4 \cdot 0 \\
8 \cdot 7\end{array}$ \\
\hline $\begin{array}{l}\text { PSY } \\
\text { PSY }\end{array}$ & 20 & $\begin{array}{l}1 \cdot 83 \\
0.0195\end{array}$ & $\begin{array}{l}0 \cdot 141 \\
0.00153\end{array}$ & $\begin{array}{l}7 \cdot 8 \\
3 \cdot 8\end{array}$ \\
\hline
\end{tabular}

Effect of iron on porphyrin synthesis. Iron deficiency sometimes leads to accumulation of porphyrin in culture media (see Lascelles, 1955); no porphyrin was detected in cultures of El Agheila Z in iron-free media PSY or PY.

Effect of iron on content of desulphoviridin. The amount of this pigment/unit wt. of organisms was little affected by the iron content of the culture medium (Table 2), in contrast to the amount of cytochrome $c_{3}$. This observation is consistent with Postgate's (1956) view that desulphoviridin is a porphyroprotein and not a haematin as supposed by Ishimoto, Koyama \& Nagai (1954a, b). 
Effect of iron on content of hydrogenase. Waring \& Werkman (1944) showed that Aerobacter indologenes was deficient in hydrogenase when grown in irondeficient media; it was of interest to see if this were also true of Desulphovibrio desulphuricans. Table 3 lists some $Q$ values for the reduction of methylene blue in hydrogen and shows that growth without Fe led to a fivefold to eightfold decline in the hydrogenase content.

\section{Table 3. Effect of iron on the hydrogenase content of Desulphovibrio desulphuricans}

D. desulphuricans strain El Agheila $Z$ organisms were harvested from iron-deficient media PY or PSY in 'iron-free' vessels (see text) after incubation for 3-5 days at $30^{\circ}$ under $\mathrm{H}_{2}+5 \% \mathrm{CO}_{2}$. The rates of hydrogen absorption with sulphate or methylene blue as electron acceptor were compared with the rates for organisms harvested from similar media but with 15 to $20 \mathrm{~m} \mu \mathrm{mole} \mathrm{Fe} / \mathrm{ml}$. added. Vessels were pre-incubated $1 \frac{1}{2} \mathrm{hr}$. before addition of substrates ; $-Q$ values $\left(\mathrm{mm}^{3} \mathrm{H}_{2}\right.$ absorbed/mg dry wt. organisms/hr.) quoted from three experiments.

\begin{tabular}{|c|c|c|c|c|c|c|}
\hline \multirow{2}{*}{$\begin{array}{l}\text { Growth } \\
\text { medium }\end{array}$} & \multicolumn{3}{|c|}{ With iron } & \multicolumn{3}{|c|}{ Without iron } \\
\hline & $-Q_{\mathrm{H}_{2}}^{M B B}$ & $-Q_{\mathbf{H}_{2}}^{8 O_{1}}$ & $-Q_{\mathrm{H}_{2}}^{\text {endogenous }}$ & $-Q_{\mathrm{H}_{2}}^{\mathrm{MB}}$ & $-Q_{\mathrm{H}}^{\mathrm{so}, "}$ & $-Q_{\mathbf{H}_{\mathbf{g}}}^{\text {endogenous }}$ \\
\hline PY & 192 & - & - & 48 & - & - \\
\hline PSY & 230 & 38 & $4 \cdot 8$ & 29 & 3.2 & $2 \cdot 6$ \\
\hline PSY & 95 & 45 & 0.5 & 31 & $3 \cdot 1$ & $2 \cdot 6$ \\
\hline
\end{tabular}

\section{DISCUSSION}

Recovery of iron as cytochrome $\mathrm{c}_{3}$. The molar extinction coefficient of cytochrome $c_{3}$, together with its relatively high iron content, provide reasons for assuming the presence of two haemin groups per molecule (Postgate, 1955). The recovery of added iron as cytochrome $c_{3}$ can therefore be calculated. For example: a culture of El Agheila $\mathrm{Z}$ in medium LSY $+5 \mathrm{~m} \mu$ mole $\mathrm{Fe} / \mathrm{ml}$. had a final bacterial density of $250 \mu \mathrm{g}$. dry wt./ml. and the organisms contained $0.091 \mu \mathrm{U} . c_{3} / g$.; hence the cytochrome accounted for $0.9 \%$ of the added iron. Similar calculations for El Agheila $Z$ grown with other concentrations of iron gave these values: recovery as $c_{3}$ from $7.5 \mathrm{~m} \mu$ mole $\mathrm{Fe} / \mathrm{ml} .: 0.78 \% ; 10 \mathrm{~m} \mu$ mole $\mathrm{Fe} / \mathrm{ml} .: \mathbf{0} \mathbf{0 8} \%$.

Clearly a large proportion of the added iron was not used for cytochrome $c_{3}$ synthesis although over $90 \%$ of it was removed from solution. It was not detectable as haematin, since treatment of the whole organisms with $\mathrm{NaOH}$, pyridine and dithionite did not increase the intensity of the $\alpha$-band of $c_{3}$, though it shifted 2 or $3 \mathrm{~m} \mu$. towards the violet; the fate of the remainder of the added iron is thus unknown. Higher concentrations of cytochrome $c_{3}$ were observed with the Hildenborough strain grown on media of unknown iron content by continuous culture procedures; the organisms used by Postgate (1956) for the preparation of cytochrome $c_{3}$ contained about $0 \cdot 20 \mu \mathrm{U}$. $c_{3} / \mathrm{g}$.

Though the concentration of cytochrome $c_{3}$ in the organisms was low compared with the amount of iron added, it was roughly proportional to the amount of iron added and was not influenced by the presence of sulphate even though the cytochrome probably acts as a carrier in sulphate reduction. Thus strain El Agheila Z of Desulphovibrio desulphuricans differed markedly from the yeast 
studied by Slonimski (1955), which formed cytochrome $c$ and many other enzymes of the respiratory cycle, adaptively, in response to the presence of its terminal electron acceptor oxygen.

Biological function of cytochrome $\mathrm{c}_{3}$. Evidence for the view that cytochrome $c_{3}$ acts as a carrier between sulphate reduction and cellular oxidation processes in Desulphovibrio desulphuricans has been discussed elsewhere (Ishimoto et al. 1954 $b$; Postgate, 1956); the present work supports this view in that organisms grown in media freed from iron by 8-hydroxyquinoline are deficient in cytochrome $c_{3}$ and can reduce sulphate only slowly. But neither this observation nor earlier evidence demonstrates conclusively that cytochrome $c_{3}$ is the natural carrier for the reduction of sulphate. The oxidation of cytochrome $c_{3}$, observed when whole organisms are incubated with sulphate, may only reflect a general change in the redox potential of organisms which are metabolizing sulphate. The ability of methyl and benzyl viologen to substitute for cytochrome $c_{3}$ in the reduction of sulphite, thiosulphate, etc., by enzymically active cell preparations suggests that the carrier action of $c_{3}$ may be merely a reflexion of its low redox potential and have no real metabolic significance. The fact that cytochrome $c_{3}$ acts as a carrier in the hydrogen-oxygen reaction, which can scarcely be of great metabolic importance for so strict an anaerobe as Desulphovibrio desulphuricans, does not strengthen confidence in the view that it is the biological carrier with other terminal electron acceptors.

I am grateful to Dr P. Slonimski for a valuable discussion of this work during its early stages. I am also indebted to Mr George Coldicott for preparing basal media and iron-free glassware, and to my colleagues of the Microbiology Group of this Laboratory for interest and encouragement. This paper is published by permission of the Director, Chemical Research Laboratory.

\section{REFERENCES}

Adams, M. E., Butlin, K. R., Hollands, S. J. \& Postgate, J. R. (1951). Role of hydrogenase in the autotrophy of Desulphovibrio. Research, Lond. 4, 425.

Barer, R. (1955). Spectrophotometry of clarified cell suspensions. Science, 121, 709.

Butlin, K. R., Adams, M. E. \& Thomas, M. (1949). The isolation and cultivation of sulphate-reducing bacteria. J. gen. Microbiol. $3,46$.

Grossman, J. P. \& Postgate, J. R. (1953). The cultivation of sulphate-reducing bacteria. Nature, Lond. 171, 600.

Grossman, J. P. \& Postgate, J. R. (1955). The metabolism of malate and certain other compounds by Desulphovibrio desulphuricans. J. gen. Microbiol. 12, 429.

Ishimoto, M., KoYama, J. \& NAGAI, Y. (1954a). A cytochrome and a green pigment of sulphate-reducing bacteria. Bull. chem. Soc. Japan, 27, 565.

Ishimoto, M., Koyama, J. \& NAGAI, Y. (1954b). Biochemical studies on sulphatereducing bacteria, IV. J. Biochem., Tokyo, 41, 763.

LASCELles, J. (1955). The synthesis of porphyrins and bacteriochlorophyll by cell suspensions of Rhodopseudomonas spheroides. Biochem. J. 62, 78.

Postgate, J. R. (1952). Growth of sulphate-reducing bacteria in sulphate-free media. Research, Lond. 5, 189.

Postgate, J. R. (1953). On the nutrition of Desulphovibrio desulphuricans: a correction. J. gen. Microbiol. 9, 440. 
Postgate, J. R. (1955). Cytochrome $c_{3}$ : a bifunctional haematohaematin. Biochim. biophys. Acta, 18, 427 .

Postgate, J. R. (1956). Cytochrome $c_{3}$ and desulphoviridin; pigments of the anaerobe Desulphovibrio desulphuricans. J. gen. Microbiol. 14, 545.

Sandell, E. B. (1944). Colorimetric Determination of Traces of Metals. New York, U.S.A.: Interscience Publishers, Inc.

SeIDell, A. (1940). Solubilities of Inorganic and Metallo-organic Compounds. 1. New York: U.S.A.: D. van Nostrand.

Slonimski, P. P. (1955). Adaptation respiratoire: développement du système hémoprotéique induit par l'oxygène. Rapports 3rd Congr. Int. Bioch. p. 242.

Waring, W. S. \& Werkman, C. H. (1942). Growth of bacteria in an iron-free medium. Arch. Biochem. $1,303$.

WARING, W. S. \& WeRKMAN, C. H. (1944). Iron deficiency in bacterial metabolism. Arch. Biochem. 4, 75.

(Received 6 February 1956) 